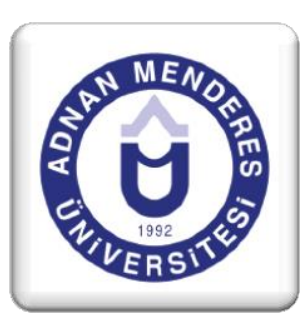

\title{
Beyin Temelli Öğrenme Yönteminin Öğrencilerin Fen Bilimleri Dersinin Erişisine Etkisi
}

\section{The Effect Of Brain Based Learning Method On Students' Achievement Of Science Lesson}

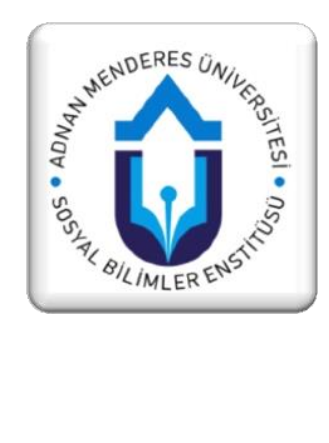

Serhat SÜRAL ${ }^{1}$

\section{Özet}

Bireyde öğrenmeyi gerçekleştiren beynin çalışma prensibine göre öğrenme öğretme sürecini organize etmek ve bu planlamanın ögrencilerin akademik başarısına ne şekilde yansıdığını görmek, bu araştırmanın önemini oluşturmaktadır. Bu çalışmanın amacı, beyin temelli öğrenme yaklaşımının, ilkokul 5. sınıf öğrencilerinin fen bilimleri dersinde "Canlılar Dünyasını Gezelim" alt öğrenme alanı ile ilgili başarıları üzerinde bir etki yaratıp yaratmadığını incelemektir. Bu çalışmada, 2013-2014 eğitim öğretim yılının bahar döneminde Denizli merkezde yer alan bir ilkokulun 5.sınıf şubelerinde öğrenim gören 58 öğrenci yer almıştır. Araştırma probleminin çözümü için ögrencilerin denkleştirilmesinde kullanılmak üzere bir anket formu, öğrencilerin akademik başarılarını ve kalıcılı̆ını ölçmek amacıyla başarı testi kullanılmıştır. Beyin temelli ögrrenme yöntemi öğrencilerin akademik başarılarını olumlu yönde etkilemiştir.

Anahtar Kelimeler:Beyin temelli öğrenme, öğrenme, fen bilimleri.

\begin{abstract}
Individuals who perform the learning brain works according to the principle to organize the learning process and students' academic success of this planning what to see that reflected in the way, it constitutes the importance of research. The purpose of this study, brain-based learning approach, 4th grade elementary school students in science lessons "Canlılar Dünyasını Gezelim" on the bottom area of learning is to examine whether have an impact on the success. In this study, the spring semester of the 2013-2014 academic year, an elementary school located in the center of Denizli branch studying in 5th grade 58 students took part. Research for the solution of the problem of balancing students a questionnaire to be used in the students' academic success and persistence test is used to measure success. Brain-based learning method has a positive impact on students' academic achieve.
\end{abstract}

Key Words: Brain-based learning, learning, science

\footnotetext{
${ }^{1}$ Arş. Gör. Dr., Pamukkale Üniversitesi Eğitim Fakültesi Sınıf Öğretmenliği ABD., ssural@pau.edu.tr.
} 


\section{Giriş}

Beyin temelli öğrenme, anlamlı öğrenme için beyin kurallarının kabul edilmesini ve öğretimin zihindeki bu kurallarla örgütlenmesini içerir. Bir başka deyişle bu yaklaşımın amacı, anlamlı bir öğrenme ve öğretme için her şeyden önce öğrenme işlevini yerine getiren beynin biyolojik yapısının ve işleyiş kurallarının benimsenmesini ve öğretme sürecinin bu işleyiş kurallarına göre yapılandırılmasını sağlamaktır (Caine ve Caine, 2002:22).

Öğrencilerin beyni bilgiyi işlemede gözlenemediğinden, öğrenme sürecinde say1lamayan bir değişkendir. Davranış̧̧ felsefeyi izleyen sınıflarda öğretmenin bilgiyi pasif öğrencilere iletmesi beklenir. Önceki bilgiler, sınıftaki öğrenme çevresi ya da öğrencilerin konuya ilgisi gibi durumlar göz önünde bulundurulmaz. Okullardan öğrencileri doğrusal düşünme ve fabrika modelinin egemen olduğu bir dünyaya katılıma hazırlamaları beklenmektedir. Bu nedenle iletimsel eğitim modeli öğrencilere yeterli biçimde verilmektedir. Bununla birlikte son yüzyılın sonlarına doğru öğrencilerde farklı niteliklere gereksinim duyulmuştur. Yaratıcı düşünme becerileri, problem çözme ve işbirliği gruplarında çalışma ortaya çıkmıştır (Stevens, 2001:56).

Nörobilim, nörodilbilim ve bilişsel psikoloji alanlarında son yıllarda beyinle ilgili pek çok çalışma yapılmıştır. Beyin araştırmalarının eğitime yansıması ile de beyin temelli öğrenme yaklaşımları önem kazanmaya başlamıştır. Yeni beyin araştırmalarının öğretme ve öğrenmede uygulanması çok önemli bir yeniliktir (Çengelci, 2005:64).

Beyin temelli öğrenme, insan beyninin yapısına ve işlevine dayanan bir öğrenme kuramıdır. Bu kuramda anahtar kavram, normal beyin süreci ile tutarlı öğrenme fırsatları sağlamadır. Beyin hakkında bilinenler "sinir sistemi, beyin, beynin biyolojik temelleri, algı, zihin ve öğrenme çalışmalarını" içeren nörobilimden gelmektedir. Nörobilim, beyin ve sinir sistemi ile bilişsel davranışlar arasında bağlantı kurmaya yardımcı olur (Brewer, 1999:65). Beyin temelli öğrenme, anlamlı öğrenme için beynin kurallarının kabul edilmesini ve öğretimin zihindeki bu kurallarla örgütlenmesini içerir. Beyinde anlamı oluşturma, bilgiyi almaktan daha çok önemlidir. Örüntüler, bağlantılar ve duygular doğrultusunda beyin anlamı oluşturur. Beyin temelli öğrenmede öğrenenler yalnızca çalıştıkları konu ile ilgili bağlantıları görmezler, aynı zamanda önceki bilgileriyle yeni bilgileri arasında ilişki kurarak anlamlı öğrenmeyi gerçekleştirirler (Caine, 2002:56).

Anlamlı öğrenmede bireyin obje ve olayların özelliklerini algılama, onları zihinde yeniden organize etme özelliği vardır. Birey, algılarını üst düzeyde genelleme ve soyutlama yaparak daha önceden öğrendikleri üzerine organize ederek özümler, yapısallaştırır, bunun sonucunda zihninde yeni bir anlam gelişir (Ülgen, 1997:71). Beyin temelli öğrenme, öğrenenler için, yaşamla iç içe zengin ve uygun deneyimlerin tasarlanması ve uygulanması; anlamın özünü kavramaya yönelik etkinliklerin planlanmasıdır. Beyin temelli öğrenmenin uygulandığı eğitim ortamları öğrenci merkezlidir. Eğitim ortamları bireylerin birbirleriyle sosyal etkileşimde bulunmalarına, fiziksel ve psikolojik bakımdan tehdit edici olmayan bir sınıf atmosferinde, dayanışma içinde, etkinliklere doğrudan katılarak, keşfederek öğrenmelerine olanak sağlayacak biçimde düzenlenir.

Beyin temelli öğrenmede, beynin işleyişi ve öğrenmenin oluşumuna ilişkin elde edilen bulgulara bağlı olarak öğretme-öğrenme sürecinde öğrencilere; düşünme için öğretme (teach for thinking), düşünmenin öğretimi (teach of thinking), düşünme ile öğretim (teach with thinking) ve düşünme hakkında öğretim (teach about thinking) yeterlikleri kazandırılmaya çalış1ır (Fogarty, 2002:41). Beyin araştırmalarından elde edilen bulguları öğretme-öğrenme sürecinde kullanan öğretmenler, nöro-eğitimciler olarak adlandırılabilecek yeni bir mesleki uzmanlık alanı oluşturmaktadırlar. Nöro-eğitimciler, disiplinler arası bakış açısıyla eğitilmekte ve gerek beynin işleyişi gerekse etkili öğretim için gereksinim duyulan anahtar kavramları bilmektedirler. Bu öğretmenler, öğrencilerin potansiyellerini ve yeteneklerini en üst düzeye çıkarabilmek için öğretme-öğrenme sürecinde beynin işleyişini temel almaktadırlar. Nöro-eğitimciler, öğrenmenin vücut-sinir sistemi bütünlüğü gerektiren biyokimyasal bir sonuç olduğunu kabul etmektedirler (Stevens ve Goldberg, 2001:81).

Beyin temelli öğrenme; öğrencilerin bilgilerini artırdıkları, örüntüler oluşturdukları, ilişkiler kurdukları, risk aldıkları güvenli ve öğrenmeyi destekleyici bir sınıf atmosferi öngörmektedir (Wagmeister ve Shifrin, 
2000:46). Bu açıdan, yapılan araştırmaların sonuçları, öğretme ve öğrenme üzerindeki bu yeni paradigmanın önemli rol oynayacağını göstermektedir (Cram ve Germinario, 2000).

Beyin temelli öğrenme yaklaşımı, bilginin ezberlenmesi değil, anlamlandırılarak kavranması ve özümsenmesidir. Burada davranışçı anlayışın yerine, bireyin beynin işlevlerini kendi sorgulayıcı tavrı, kendi seçimi ve inisiyatifi ile kullandığı öğrenme yaklaşımıdır. Beyin temelli öğrenmenin uygulanması için birtakım sürecin varlığından söz edilebilir. Bu yaklaşımın uygulanabilmesi için amaç olarak belirlenmesi ve birbiri ile etkileşimli üç sürecin varlığından bahsedilebilir (Caine ve Caine, 2002: Akt. Baş, 2001: 490):

\section{Rahatlatılmış Uyanıklık (Relaxed Alertness)}

Güvenlik, rahatlık ve içsel motivasyonu içerir. Stres ortamından arınma, beyinsel yorgunluğun olmaması, duygusal farkındalık, öz güven duygusu, bilişsel farkındalık gibi süreçlerden oluşur. Birey rahat olduğu zaman, beyin olarak öğrenmeye istekli olur; fakat eğer o güdülenme sağlanamazsa öğrenme eylemi gerçekleşmez. Bu bağlamda bu aşama önem arz etmektedir.

\section{Derinlemesine Daldirma (Immersion)}

Anlamlı içerik odaklanmas1, işbirliği, zengin öğrenme ortam1, tematik öğretim, deneyimler, işbirliği, birliktelik, bir amaç doğrultusunda bütünlük içinde program gibi süreçlerden oluşmaktadır. $\mathrm{Bu}$ aşama, bireylerin baş başa kaldıkları içeriğe yoğunlaşma süreçlerinden oluşmaktadır.

\section{Aktif Süreçleme (Active Processing)}

Sorgulama, eleştirel bakış, içerik düzenlenmesi, anlamlandırma, korkusuzluk, bağlam ve bağlantıyı kapsamaktadır.

İnsanoğlu var oluşundan bu yana öğrenmeye ilgi duymuş, öğrenmenin nasıl gerçekleştiğini her zaman merak etmiş ve bu konuda çeşitli araştırmalar yapmıştır. Son yıllarda teknolojinin yardımıyla da artan araştırmalar öğrenme sürecinin daha çok beyinle ilgili olduğunu ortaya koymuştur (Jensen, 2006:32; Duman, 2007:91). Öğretim programları içerisinde öğrenciye merak duygusunu kazandırmaya en yatkın, araştırma ve keşfetme becerisini geliştirmeye en uygun ders de şüphesiz programda yeni adiyla yer alan fen bilimleri dersidir. Son hazırlanan fen bilimleri programında da yer verilen bu becerileri öğrenciye kazandırmada, öğrenmeyi gerçekleştiren beynin çalışma prensibini rehber edinmek gerekmektedir. Süreçte uygulanan programdaki öğrenme alanları ve tematik yaklaşım, beyin temelli öğrenme modeline oldukça yatkınlık göstermektedir. Fogarty'nin (2002) de belirttiği gibi beyin temelli öğretme-öğrenme sürecinde temaların kullanımı önemlidir. Çünkü temalar içerikte yer alan kavram ve becerileri öğrencilerin içselleştirmelerine yardımcı olarak öğretimin bireysel olarak anlamlı olmasını sağlar. Bununla birlikte, temaların kullanımı, bir konu alanından başka bir konu alanına açık, belirgin ve bilinen bağlantıların kurulmasını sağlar. Böylece, öğrenilen bilgilerin hatırlanması kolaylaşır ve güçlü nöral yollar oluşur.

Fen konuları, çeşitli akademik alanların ayrılmaz bir parçasıdır ve gerçek yaşamın birçok durumu ile iç içedir. Öğrenciler, fizik kurallarına, kimyasal bileşiklerin tanımlarına ve hücre yapısına ilişkin sayısız durumla karşılaşırlar. Ayrıca, ekosistem, depremler ve volkanik olaylara ilişkin endişelerle karşılaşırlar. Yaşamları süresince öğrencilerin, dünya dışı yaşam, gezegenlerin hareketleri ve güneş ve ay tutulmaları ilgilerini çeker ve öğrenciler bunlardan etkilenirler. Öğrencilerin, fen alanındaki sürekli gelişmeleri tam ve doğru bir şekilde anlamaları için, temel fen kavramlarının ve becerilerinin formal eğitim sürecinde kazandırılması önemlidir (Fogarty, 2002:43).

Fen bilgisi dersinde öğretme-öğrenme süreci araştırma-soruşturma temelli olmalıdır. Beyin, doğal bir şekilde anlam arayışında olduğu ve bağlantılar oluşturmaya çalıştığ 1 için araştırma soruşturma temelli fen öğretimi beyin temelli öğrenme ile uyumlu bir şekilde çalışacaktır (Mangan, 1998:50). Beyin temelli öğrenme, öğretmenlerin öğretme-öğrenme sürecini kolaylaştırmalarına yardımcı olmaktadır (Özden, 2005:3).

Beyin temelli öğrenme ile ilgili yapılan çalışmalar bu yaklaşımın öğrencilerin akademik başarılarını artırdığını (Demirel, ve diğ. 2002; Cengiz, 2004; Duman, 2006; Çengelci, 2007; Erduran Avc1, 2007; Keleş, 2007; Aydın, 2008; Çelebi, 2008; Özden ve Gültekin, 2008; Baş, 2010), kalıcı ve anlamlı öğrenmeyi 
sağladığını (Demirel, ve diğ. 2002; Baştuğ, 2007; Çengelci, 2007; Erduran Avc1, 2007), öğrenilen bilgilerin hatırlanma düzeyini artırdı̆̆ını (Özden ve Gültekin, 2008) göstermektedir.

Bilgi çağının yaşandığı günümüzde, eğitim sistemlerinin temel amacı öğrencilere var olan bilgileri aktarmaktan çok bilgiye ulaşma becerileri kazandırmaktır. $\mathrm{Bu}$ ise, üst düzey zihinsel süreç becerileri ile gerçekleştirilebilir. Bir başka deyişle, ezberlemekten çok kavrayarak öğrenme, karşılaşılan yeni durumlarla ilgili problem çözebilme ve bilimsel süreç becerilerinin öğrencilere kazandırılması gerekmektedir. $\mathrm{Bu}$ özelliklerin kazandırıldığı derslerin başında da fen bilgisi gelir. Fen Bilgisini anlamlı bir biçimde öğrenmek, öğrencilerin öğretme-öğrenme sürecinde olgular, insanlar ve nesnelerle zihinsel ve fiziksel olarak etkileşimde bulunmasına ve önceki bilgilerini yeni durumlara aktarmalarına bağlıdır. Öğrenci tarafından bireysel olarak anlamlandırılarak içselleştirilmiş olan bilginin, ileriki yaşamında onu bırakmayacağı düşünüldüğünde, bilimsel süreç becerilerini kazandırmayı ve kullandırmayı amaçlayan Fen Bilgisi dersinde, geleneksel öğretim yöntemleri ile öğrencilere anlamayı, düşünmeyi, sorgulamay1, üretmeyi öğretmek olanaklı görünmemektedir (Özden, 2005:32).

$\mathrm{Bu}$ bağlamda beyin temelli öğrenme, insan beyninin yetenek ve yapabileceklerinden daha fazlasını işe sokarak, eğitimcilerin kendi rollerini yeniden tanımlamalarına ve öğrencilerin anlamlı, ilişkilendirilen ve bağlantılı bilgi oluşturabilmelerini ve bunun kalıcılığını devam ettirebilmeleri için temel oluşturur (Avcı, 2007).

Sonuç olarak, bireyde öğrenmeyi gerçekleştiren beynin çalışma prensibine göre öğrenme öğretme sürecini organize etmek ve bu planlamanın öğrencilerin akademik başarısına ne şekilde yansıdığını görmek, bu araştırmanın önemini oluşturmaktadır.

$\mathrm{Bu}$ çalışmanın amacı, beyin temelli öğrenme yaklaşımının, ilkokul 5. sınıf öğrencilerinin fen bilimleri dersinde "Canlılar Dünyasını Gezelim" alt öğrenme alanı ile ilgili başarıları üzerinde bir etki yaratıp yaratmadığını incelemektir.

Araştırmanın problem cümlesi, "Fen bilimleri dersinde beyin temelli öğrenmenin akademik başarıya ve kalıcılığa etkisi”ni belirlemektir. Belirlenen bu temel probleme bağlı olarak, aşağıdaki sorulara yanıt aranmışıtır:

1. Fen bilimleri dersinde, beyin temelli öğrenme yaklaşımı uygulanan deney grubu ile geleneksel öğretimin uygulandığı kontrol grubundaki öğrencilerin akademik başarıları arasında anlamlı bir fark var mıdır?

2. Fen bilimleri dersinde, beyin temelli öğrenme yaklaşımı uygulanan deney grubu ile geleneksel öğretimin uygulandığ 1 kontrol grubu arasında öğrenmenin kalıcılığı bakımından anlamlı bir fark var mıdır?

3. Fen bilimleri dersinde, beyin temelli öğrenme yaklaşımının uygulandığı deney grubu ile geleneksel öğretimin uygulandığ kontrol grubundaki öğrencilerin akademik başarılarının kalıcılığ üzerinde anlamlı bir fark var midır?

\section{Materyal ve Metot}

\subsection{Araştırmanın Modeli}

Beyin temelli öğrenme yönteminin öğrencilerin fen başarısına etkisini sınamaya yönelik olan bu araştırma, deneme modellerinden "öntest - sontest kontrol gruplu model'e göre desenlenmiş ve gerçekleştirilmiştir. $\mathrm{Bu}$ desen özellikle eğitim araştırmalarında yaygın olarak kullanılan deneysel desenlerden biridir.

Ön test-son test kontrol gruplu deseni kısaca; deney ve kontrol gruplarına yansız olarak atanan deneklerin deneysel işlemden önce ve sonra ölçüldüğ̈̈ desen olarak ifade etmektedir (Kerlinder, 1973). Bu araştırmada da, öntest-sontest kontrol gruplu modelde biri deney, diğeri de kontrol grubu olmak üzere yansız atama yöntemiyle iki grup oluşturulmuş; iki grupta da deney öncesi ve deney sonrası ölçmeler yapılmıştır. 


\section{2. Çalışma Grubu}

Bu çalışmada, 2013-2014 eğitim öğretim yılının bahar döneminde Denizli merkezde yer alan bir ilkokulun 5.sınıf şubelerinde öğrenim gören 58 öğrenci yer almıştır. Deney ve kontrol gruplarının belirlenmesinde, yansız atama yöntemi benimsenmiş ve bu amaçla 5-A ve 5-B sınıfları arasında kura çekilmiştir. Çekilen kura sonunda, 5-A sınıfi deney grubu, 5-B sınıfı da kontrol grubu olarak belirlenmiştir. Deney grubu olan 5-A sınıfinda 30 öğrenci, kontrol grubu olan 5-B sınıfinda ise 28 öğrenci bulunmaktadır. Öğrencilerin kişisel bilgiler anketine verdikleri yanıtlarda belirttikleri özellikler ve ön testten aldıkları puanlar doğrultusunda deney ve kontrol grubundan 24'er öğrenci denkleştirilmiştir. Deney ve kontrol grubunda öğretimi aynı öğretmen sürdürmüştür. Araştırmacı deney grubunda öğretmenle birlikte derslere katılmıştır. Deney grubunda araştırmacının hazırladığı ders planları uygulanmıştır. Kontrol grubunda ise öğretmen geleneksel ögretim yöntemlerine göre ders işlemiştir.

\subsection{Veri Toplama Aracının Geliştirilmesi}

Araştırma probleminin çözümü için öğrencilerin denkleştirilmesinde kullanılmak üzere bir anket formu, öğrencilerin akademik başarılarını ve kalıcılığını ölçmek amacıyla başarı testi kullanılmıştır.

Araştırmada veri toplama aracı olarak kullanılan başarı testi, kişisel bilgiler anketi ve ders materyalleri ile görü almaya yönelik anket formu araştırmacı tarafından geliştirilmiştir. Araştırma kapsamında "Canlılar Dünyasını Gezelim” alt öğrenme alanında öğrencilerin başarılarını ve öğrenmenin kalıcılığını ölçmeye yönelik 25 soruluk dört seçenekli çoktan seçmeli erişi testi hazırlanmıştır. Testlerin kapsam geçerliğinin sağlanması için testteki soruların tüm konu içeriğini örneklemesine ve kapsadığı soruların her birinin ölçmek istediği davranış1 en iyi derecede ölçmesine özen gösterilmiştir.

\subsection{Deneysel Çalışmanın Uygulama Süreci}

Veri toplama aracının hazırlanması ve okul müdürlüğünden izin alınmasından sonra deney ve kontrol grupları belirlenmiştir. Deney grubunda beyin temelli öğrenme süreci başlatılmıştır. Çalışma, araştırmacı ve öğretmen tarafından birlikte yürütülmüş; öğretmene beyin temelli öğrenme hakkında genel bilgiler verilmiştir.

Deney ve kontrol gruplarının belirlenmesinden sonra, her iki gruptaki örencilere, Fen bilimleri dersinde beyin temelli öğrenmenin öğrencilerin başarılarına ve öğrenmenin kalıcılık düzeyine etkisini belirlemek amacıyla bir araştırmanın planlandığı ve kendilerinin de bu araştırmanın denekleri olarak seçildiği söylenmiş̧ir. Daha sonra her iki gruba, "Canlılar Dünyasını Gezelim" alt öğrenme alanı erişi testi ön test olarak uygulanmıştır. Öğretmen ve öğrencilere çalışmanın niteliği ayrıntılı olarak açıklandıktan sonra, haftada üç ders saati olmak üzere yedi hafta süreli bir öğretim uygulamasına geçilmiştir.

Fen bilimleri dersi, deney grubunda beyin temelli öğrenme ile kontrol grubunda ise geleneksel öğretimle işlenmiştir. Yedi hafta sonunda alt öğrenme alanı ile ilgili etkinlikler tamamlandığında her iki gruba "Canlılar Dünyasını Gezelim" alt öğrenme alanı erişi testi son test olarak uygulanmıştır. Erişi testinin son test olarak uygulanmasından 18 gün sonra, öğrenmedeki kalıcılık düzeyini ölçmek için erişi testi yeniden uygulanmıştır. Ön test, son test ve kalıcılık testi uygulamaları ile öğrencilerin ön test, son test ve kalıcılık testi puanları elde edilmiştir.

Araştırmacı, öğretme-öğrenme sürecini beyin temelli öğrenme yaklaşımının üç temel aşaması olan ahenkli biçimde daldırma, rahatça almaya hazır olma ve aktif süreçleme basamaklarına uygun olarak düzenlemiştir.

Daldırma aşamasında, öğrencilerin konuya ilişkin genel bilgi edinmelerine yardımcı olmak amacıyla powerpoint sunumları, çizgi filmler, belgesel filmler ve çeşitli resimlerden yararlanılmıştır. Birden çok duyuya hitap eden sunumlardan sonra öğrencilerden konunun özelliğine göre bireysel çalışmalara ya da grup çalışmalarına yönelmeleri sağlanmıştır. Rahatça almaya hazır olma aşamasında, öğrencilerin işbirlikli çalışmaları ve bir konuda uzmanlaşmalarını sağlamak için heterojen gruplar oluşturulmuş ve öğrencilerin daldırma aşamasında edindikleri bilgileri özümsemeleri sağlanmıştır. Bu aşamada, öğrencilerin konuya ilişkin şemalar oluşturmalarını kolaylaştırmak için araştırmacı tarafından çalışma yaprakları hazırlanmış, öğrencilerden konuya ilişkin hikâyeler oluşturmaları istenmiştir. Ayrıca, öğrencilere konuya ilişkin projeler 
üretmeleri için firsat sunulmuş, küme çalışmalarına ilişkin elde ettikleri sonuçları sınıfla paylaşmaları ve grupların uzmanlık alanına ilişkin sorular sormaları cesaretlendirilmiştir. Aktif süreçleme aşamasında ise, öğrenilen bilgilerin kalıcılığını sağlamak, öğrencilerin edinilen bilgileri yapılandırmalarını ve daha önceki aşamalarda öğrendiklerini yeni durumlara uygulamalarını kolaylaştırmak amacıyla benzetimlerden, tartışmalarından, oyunlardan ve dramalardan yararlanılmıştır.

Kontrol grubunda ise, öğrencilerin fen bilimleri dersinde ilgili konuları okumaları, anlatmaları, öğretmenin konu ile ilgili açıklamalarını dinlemeleri, deneylerin öğretmen tarafından gösteri biçiminde gerçekleştirilmesine yönelik öğretmen merkezli öğretim anlayışı benimsenmiştir.

\subsection{Verilerin Analizi}

Deney ve kontrol gruplarının ön test ve son test puanları elde edildikten sonra, grupların ortalama puanları ile puan dağılımlarının standart sapmaları hesaplanmıştır. Gruplar arası karşılaştırmalarda $t$ testinden yararlanılmış ve anlamlılık düzeyi .05 olarak benimsenmiş; istatistiksel çözümlemelerde SPSS 13 paket programından yararlanılmıştır.

\section{Bulgular}

1. "Fen bilimleri dersinde, beyin temelli öğrenme yaklaşımının uygulandığı deney grubu ile geleneksel öğretimin uygulandığı kontrol grubundaki öğrencilerin akademik başarıları arasında anlamlı bir fark var mıdır?" sorusunu yanıtlamak amacıyla, deney ve kontrol gruplarındaki örencilere başarılarını ölçmek amacıyla ön test niteliğinde başarı testi uygulanmıştır. Deneklerin bu testten aldıkları puanların aritmetik ortalamaları ve standart sapmaları hesaplanmış, ortalamalar arasındaki fark t testi ile sınanmıştır. Deney ve kontrol gruplarının ön test niteliğindeki başarı testlerinden aldıkları puanlar Tablo 1'de gösterilmiştir.

Tablo 1. Deney ve Kontrol Gruplarının Başarı Testinden Aldıkları Ön test Puanlarına İlişkin Bulgular

\begin{tabular}{|l|l|l|l|l|l|l|}
\hline $\begin{array}{l}\text { Öğrenci } \\
\text { Grupları }\end{array}$ & $\mathbf{N}$ & $\mathbf{X}_{\text {ort }}$ & $\mathbf{S s}$ & $\mathbf{t}$ & $\mathbf{S d}$ & $\mathbf{P}$ \\
\hline Deney grubu & 30 & 44.51 & 9.475 & & 39 & .120 \\
\hline $\begin{array}{l}\text { Kontrol } \\
\text { Grubu }\end{array}$ & 28 & 44.21 & 6.415 & .131 & 39 & \\
\hline
\end{tabular}

t tablo=2.021

Tablo 1'de görüldüğü üzere, kontrol grubundaki öğrencilerle deney grubundaki öğrencilerin ön testlerden elde ettikleri ortalama puanlar arasında kontrol grubu lehine 0.30 puanlık bir fark bulunmaktadır. Bu farkın istatistiksel bakımdan anlamlı olup olmadığını sınamak amacıyla, grupların ortalama puanlarına t testi uygulanmış ve $\mathrm{t}=0.131$ değeri bulunmuştur. Bu değer 39 serbestlik derecesindeki 2.021 değerinin altındadır. Elde edilen sonuç, her iki grubun aritmetik ortalamaları arasındaki farkın anlamlı olmadığını göstermektedir. Deney ve kontrol grubundaki öğrencilerin, fen bilimleri dersindeki başarıları bakımından deney öncesi durumları arasında istatistiksel bakımdan anlamlı bir fark olmadığı sonucunu göstermektedir.

Bir başka deyişle, deney ve kontrol grubunda yer alan öğrencilerin deney öncesinde Canlılar Dünyasını Gezelim alt öğrenme alanındaki başarıları arasında istatistiksel bakımdan anlamlı fark yoktur.

2. "Fen bilimleri dersinde, beyin temelli öğrenme yaklaşımının uygulandığı deney grubu ile geleneksel öğretimin uygulandığı kontrol grubundaki öğrencilerin akademik başarıları arasında anlamlı bir fark var mıdır?" sorusunu yanıtlamak amacıyla, deney ve kontrol gruplarındaki örencilere başarılarını ölçmek amacıyla son test niteliğinde başarı testi uygulanmıştır. Deneklerin bu testten aldıkları puanların aritmetik ortalamaları ve standart sapmaları hesaplanmış, ortalamalar arasındaki fark $t$ testi ile sınanmıştır. Deney ve kontrol gruplarının son test niteliğindeki başarı testlerinden aldıkları puanlar Tablo 2'de gösterilmiştir. 
Tablo 2. Deney ve Kontrol Gruplarının Başarı Testinden Aldıkları Son Test Puanlarına İlişskin Bulgular

\begin{tabular}{|l|l|l|l|l|l|l|}
\hline $\begin{array}{l}\text { Öğrenci } \\
\text { Grupları }\end{array}$ & $\mathbf{N}$ & $\mathbf{X}_{\text {ort }}$ & $\mathbf{S s}$ & $\mathbf{t}$ & $\mathbf{S d}$ & $\mathbf{P}$ \\
\hline Deney grubu & 30 & 68.55 & 8.241 & & 41 & .007 \\
\hline $\begin{array}{l}\text { Kontrol } \\
\text { Grubu }\end{array}$ & 28 & 59.54 & 9.698 & 2.458 & & \\
\hline
\end{tabular}

t tablo=2.021

Tablo 2'de görüldüğü üzere, deney grubundaki öğrencilerle kontrol grubundaki öğrencilerin son testten aldıkları puan ortalamaları arasında deney grubu lehine yaklaşık 9 puanlık fark bulunmaktadır. Bu farkın anlamlı olup olmadığ $\mathrm{t}$ testi ile sınanmış ve $\mathrm{t}=2.458$ değeri bulunmuştur. Bulunan bu değer, 41 serbestlik derecesi ve .05 anlamlılık düzeyinde 2.021 tablo değerinden büyüktür. Bu sonuç, deney ve kontrol gruplarında uygulanan öğretimin birbirinden farklı etkililiğe sahip olduğunu göstermektedir. Bu bulgu, Fen Bilimleri dersinde öğrencilerin başarılarını artırmada, beyin temelli öğrenme yaklaşımının, geleneksel öğretimden daha etkili olduğunu ortaya koymaktadır.

Böylece, Fen Bilimleri dersinde beyin temelli öğrenme yaklaşımı uygulanan deney grubu ile geleneksel öğretimin uygulandığı kontrol grubundaki öğrencilerin akademik başarıları arasında deney grubu lehine anlamlı bir fark olduğunu ileri süren birinci denence doğrulanmış bulunmaktadır.

3. "Fen bilimleri dersinde, beyin temelli öğrenme yaklaşımının uygulandığı deney grubu ile geleneksel öğretimin uygulandığı kontrol grubundaki öğrencilerin akademik başarılarının kalıcılığ üzerinde anlamlı bir fark var mıdır?" sorusunu yanıtlamak amacıyla, deney ve kontrol gruplarındaki öğrencilere başarılarını ölçmek amacıyla başarı testi son test aşamasından sonra kalıcılık niteliğinde tekrar uygulanmıştır. Deneklerin bu testten aldıkları puanların aritmetik ortalamaları ve standart sapmaları hesaplanmış, ortalamalar arasındaki fark $t$ testi ile sınanmıştır. Deney ve kontrol gruplarının ön test niteliğindeki başarı testlerinden aldıkları puanlar Tablo 3'te gösterilmiştir.

Tablo 3. Deney ve Kontrol Gruplarının Kalıcılık Düzeylerine İlişskin Uygulanan Başarı Testinden Aldıkları Puanlara İlişkin Bulgular

\begin{tabular}{|l|l|l|l|l|l|l|}
\hline $\begin{array}{l}\text { Öğrenci } \\
\text { Grupları }\end{array}$ & $\mathbf{N}$ & $\mathbf{X}_{\text {ort }}$ & Ss & $\mathbf{t}$ & Sd & $\mathbf{P}$ \\
\hline $\begin{array}{l}\text { Deney } \\
\text { grubu }\end{array}$ & 30 & 67.524 & 7.201 & 2.903 & 39 & .012 \\
\hline $\begin{array}{l}\text { Kontrol } \\
\text { Grubu }\end{array}$ & 28 & 60.154 & 9.718 & & & \\
\hline
\end{tabular}

t tablo=2.021

Tablo 3'e göre, deney grubundaki örencilerle, kontrol grubundaki örencilerin kalıc1lık testinden elde ettikleri ortalama puanlar arasında deney grubu lehine 7.40 puanlık bir fark söz konusudur. Bu farkın anlamlı olup olmadığını sınamak için, grupların ortalama puanlarına $t$ testi uygulanmış ve $t=2.903$ değeri bulunmuştur. $\mathrm{Bu}$ 
değer, 39 serbestlik derecesinin 0.05 anlamlılık düzeyindeki 2.021 değerinin üstünde bulunmaktadır. $\mathrm{Bu}$ sonuç, deney ve kontrol gruplarında uygulanan öğretimin birbirinden farklı etkililiğe sahip olduğunu göstermektedir. Bir diğer deyişle, bu araştırma, Fen bilimleri dersinde öğrenilen bilgilerin daha kalıcı olması bakımından, beyin temelli öğrenme yaklaşımının, geleneksel öğretimden daha etkili olduğunu ortaya koymaktadır.

\section{Tartışma ve Sonuç}

4+4+4 eğitim sistemine geçildikten sonra isminde, uygulanan sınıf düzeylerinde yapılanmaya giden eski adıyla fen ve teknoloji, yeni adıyla fen bilimleri dersi üzerine yapılan deneysel çalışmada bağımsız değişken olarak beyin temelli öğrenme yöntemi tercih edilmiştir. Buna göre beyin temelli öğrenmenin öğrencilerin fen bilimleri dersindeki başarısı üzerindeki etkisi incelenmiştir. İlk olarak kontrol grubu ile deney grubu arasında ön test puanları incelenmiş ve anlamlı fark bulunmamıştır. Sürecin sonunda ise son test puanlarına göre bakıldığında deney grubunun lehine anlamlı farklılık tespit edilmiş ve beyin temelli öğrenmenin öğrencilerin akademik başarısına olumlu etki ettiği görülmüştür.

Baş'ın (2010) beyin temelli öğrenme üzerine yapmış olduğu çalışmada ve Odabaşı ve Celkan'ın (2010) çalışmalarında da beyin temelli öğrenmenin olumlu etkileri gözlenmiş̧tir. Saleh'in (2012) deneysel çalışmasında da deney grubunun lehine anlamlı sonuçların olduğu görülmektedir. Yine Çengelci'nin (2005) sosyal bilgiler dersi içerisinde beyin temelli öğrenme yöntemini kullanarak yaptığı deneysel çalışmada, deney grubunun lehine anlamlı sonuçlara ulaşmıştır.

Ayrıca beyin temelli öğrenme yönteminin uygulandığı sınıflarda öğrencilerin akademik başarıları ya da erişileri, bu yöntemin uygulanmadığı sınıflara göre daha yüksek bulunuştur. Bu araştırmanın sonuçları ile yukarıda ifade edilen araştırmaların sonuçları tutarlılık göstermektedir. Ayrıca, bunun dışında Erduran-Avcı (2007), Özden (2005), Çengelci (2005), Tüfekçi (2005) ve Özden ve Gültekin (2008), yapmış oldukları araştırmalarda Beyin Temelli Öğrenme yönteminin yalnızca öğrencilerin akademik başarıları ya da erişi düzeyleri üzerinde etkili olmadığını, ayrıca, bu yöntemin uygulandığı sınıflardaki öğrencilerin edindikleri bilgilerin daha kalıcı izli olduklarını saptamışlardır.

$\mathrm{Bu}$ çalışma ile elde edilen bulgulara göre, beyin temelli öğrenme yaklaşımı, öğrencilerin Fen bilimleri dersindeki akademik başarılarını artırdığı söylenebilir. Beyin temelli öğrenme yaklaşımının, öğrenmenin kalıcılık düzeyini artırmada geleneksel öğretime göre daha etkili olduğu vurgulanabilir. Öğrenciler beyin temelli öğrenmeyi daha kolay, kalıcı ve zevkli bir öğrenme yolu olarak gördüklerini belirtmektedirler. Araştırmanın ortaya koyduğu bulgular ışığında fen bilimleri dersinde; öğrencilerin akademik başarılarını ve öğrenmenin kalıcılık düzeyini artırmada beyin temelli öğrenme yaklaşımından yararlanma yoluna gidilebilir. 


\section{KAYNAKLAR}

AVCI, D.E. (2007). Beyin Temelli Öğrenme Yaklaşımının İlköğretim 7. Sınıf Öğrencilerinin Fen Bilgisi Dersindeki Başarı, Tutum Ve Bilgilerinin Kalıcılı̆̆ı Üzerine Etkisi. Yayımlanmamış Doktora Tezi. Gazi Üniversitesi. Ankara.

AYDIN, S. (2008). Beyin Temelli Öğrenme Kuramına Dayalı Biyoloji Eğitiminin Akademik Başarı Ve Tutum Üzerine Etkisi. Yayımlanmamış Yüksek Lisans Tezi, Gazi Üniversitesi Eğitim Bilimleri Enstitüsü, Ankara.

BAŞ, G. (2010). Beyin Temelli Öğrenme Yönteminin İngilizce Dersinde Öğrencilerin Erişilerine Ve Derse Yönelik Tutumlarına Etkisi. Illköğretim Online, 9(2), 488-507.

BREWER, J. (1999). Brain Based Learning: The New Learning Model?. ProSeminar A: Design Dr. Diana McGrath.

CAİNE, N.M.; Caine, G. (2002). Beyin temelli öğrenme (Çev.Gülten Ülgen). Nobel Yayıncılık. Ankara.

CENGiZ, Y. (2004). Yabancı Dilde Sözcük Öğretimine Müzik Kullanımının Etkilerinin Beyin Temelli Öğrenme Kuramı Işı̆̆ında Araştırılması. Yayımlanmamış Yüksek Lisans Tezi, Ankara Üniversitesi Sosyal Bilimler Enstitüsü, Ankara.

CRAM, H. G.; Germinario, V. (2000). Leading and Learning School: Brain-Based Practices. London: The Scrarecrow Pres, Inc.

ÇELEBİ, K. (2008). Beyin Temelli Öğrenme Yaklaşımının Öğrenci Başarısı Ve Tutumuna Etkisi. Yayımlanmamış Yüksek Lisans Tezi, Selçuk Üniversitesi Fen Bilimleri Enstitüsü, Konya.

ÇENGELCİ, T. (2007). Sosyal Bilgiler Dersinde Beyin Temelli Öğrenmenin Akademik Başarıya Ve Öğrenmenin Kalıcılığına Etkisi. İlköğretim Online, 6(1), 62-75.

ÇENGELCİ, T. (2005). Sosyal Bilgiler Dersinde Beyin Temelli Öğrenmenin Akademik Başarıya Ve Kalıcılı̆̆a Etkisi. Yayımlanmamış Yüksek Lisans Tezi. Anadolu Üniversitesi. Eskişehir.

DEMIREL, Ö.; Erdem, E.; Koç, F.; Köksal, N.; Şendoğdu, M. C. (2002). Beyin Temelli Öğrenmenin Yabanc1 Dil Öğretimindeki Yeri. Marmara Üniversitesi Atatürk Eğitim Fakültesi Ĕ̈itim Bilimleri Dergisi, 15, 123-136.

DUMAN, B. (2007). Neden Beyin Temelli Öğrenme? Ankara: Pegem A Yayıncılık.

ERDURAN, A. D. (2007). Beyin Temelli Öğrenme Yaklaşımının İlköğretim 7. Sinıf Öğrencilerinin Fen Bilgisi Dersindeki Başarı, Tutum Ve Bilgilerinin Kalıcılı̆̆ Üzerine Etkisi. Yayımlanmamış Doktora Tezi, Gazi Üniversitesi Eğitim Bilimleri Enstitüsü, Ankara.

FOGARTY, R. (2002). Brain Compatible Classrooms. İkinci Bask1. IL: Skylight Professional Development.

JENSEN, E. (2006). Beyin Uyumlu Öğrenme. Ahmet Doğanay (Çev.). Adana: Nobel Kitabevi.

KELEŞ, E. (2007). Altıncı Sinıf Kuvvet ve Hareket Ünitesine Yönelik Beyin Temelli Öğrenmeye Dayalı Web Destekli Öğretim Materyalinin Geliştirilmesi Ve Etkililiğinin Değerlendirilmesi. Yayımlanmamış Doktora Tezi, Karadeniz Teknik Üniversitesi Fen Bilimleri Enstitüsü, Trabzon.

KERLINGEr, F. N. (1973). Foundations of Behavioral Research. New York: Holt, Rinehart \& Winston. 
MANGAN, M. A. (1998). Brain Compatible Science. Arlington Heights. Skylight Professional Development,

ODABAŞI,B.; Celkan, H. Y.(2010). Beyin Temelli Öğrenme Yaklaşımının 12.Sınıf Öğrencilerinin Başarıları Üzerine Etkisi. Ç.Ü. Sosyal Bilimler Enstitüsü Dergisi, 19(3),87-104.

ÖZDEN, M. (2005). Fen Bilgisi Dersinde Beyin Temelli Öğrenmenin Akademik Başarıya Ve Hatırlama Düzeyine Etkisi. Yayımlanmamış Yüksek Lisans Tezi. Anadolu Üniversitesi. Eğitim Bilimleri Enstitüsü. Eskişehir.

ÖZDEN, M.; Gültekin, M. (2008). The Effects Of Brain-Based Learning On Academic Achievement And Retention Of Knowledge İn Science Course. Electronic Journal of Science Education, 12(1), 1-17.

SALEH, S. (2012).The Effectiveness of Brain-Based Teaching Approach in Dealing with the Problems of Students' Conceptual Understanding and Learning Motivation Towards Physics. Educational Studies. 38(1), 19-29.

STEVENS, J. ve Goldberg D. (2001). For The Learner's Sake: Brain Based Instruction For The 21st Century. ABD: Zephyr.

STEVENS, J. (2001). For The Learners' Sake: Brain-Based Instruction For The 21st Century. Tucson: Zephyr Press.

TÜFEKÇİ, S. (2005). Beyin Temelli Öğrenmenin Erişiye, Kalıcılı̆̆a, Tutuma ve Öğrenme Sürecine Etkisi. Yayınlanmamış Doktora Tezi. Hacettepe Üniversitesi Sosyal Bilimler Enstitüsü, Ankara.

ÜLGEN, G. (1997). Eğitim Psikoloji. İstanbul: Alkım Yayınevi.

WAGMEİSTER, J. \& Shifrin, B. (2000). Thinking Differently, Learning Differently. Educational Leadership, Nowember, 45-48. 